\title{
Biotic homogenization of coral assemblages along the Florida reef tract
}

\author{
Scott G. Burman, Richard B. Aronson, Robert van Woesik* \\ Department of Biological Sciences, Florida Institute of Technology, 150 West University Blvd., Melbourne, Florida 32901, USA
}

\begin{abstract}
We tested the hypothesis that coral assemblages along the Florida reef tract have recently become more biologically homogeneous than they were in the past. We used a database that consisted of a probabilistic, 2 stage, stratified-random survey design to assess the condition of stony corals every summer from 2005 to 2010 . At each of the 1176 sites in 9 putative subregions, examined over the 6 yr period, all coral colonies $>4 \mathrm{~cm}$ were identified to species and their diameters were measured within replicated $10 \mathrm{~m}^{2}$ belt transects. This approach provided detailed spatial information on the species composition and size-frequency distributions of coral assemblages. Coral assemblages showed a nested relationship, decreasing in diversity and abundance north of $25^{\circ} 40^{\prime} \mathrm{N}$. A comparison with previous studies suggested that major declines in recent decades in the primary reef-building corals Acropora palmata, Acropora cervicornis, and Montastraea spp. have homogenized assemblages across depths and reef zones. Of the 9 putative subregions, 6 were found to be redundant on the basis of coral composition. Florida's reefs currently support a simpler coral assemblage than they did in the past, dominated by a small number of eurytopic, generalist species. The assemblages may be more stable now than during the previous several decades, but there has been a fundamental change in their composition and function. Through loss of the dominant reef-building coral species, the reefs of the Florida reef tract have lost the capacity to construct reef framework.
\end{abstract}

KEY WORDS: Biotic homogenization $\cdot$ Coral reef $\cdot$ Florida reef tract $\cdot$ Florida Keys $\cdot$ Corals Resale or republication not permitted without written consent of the publisher

\section{INTRODUCTION}

Biotic homogenization is the trend toward increasing similarity of species assemblages at different locations through time (Olden \& Poff 2003). Homogenization can be caused by invasive species reducing or eliminating native species in a particular habitat (e.g. the green alga Caulerpa taxifolia invading the Mediterranean Sea; Jousson et al. 1998), or by the loss of dominant species that dominate particular habitats and define zones. The loss of species often reduces stability and resilience (Doak et al. 1998, Tilman et al. 1998, Elmqvist et al. 2003, Thrush et al. 2008), and, as a result, biotic homogenization may also change the behavior of systems (Rooney et al.
2004). The catastrophic decline of coral populations on Caribbean reefs in recent decades may have reduced the spatial variability of coral assemblages at multiple scales, potentially compromising ecosystem functions. We tested the hypothesis that the coral assemblages of the Florida reef tract have become more spatially homogeneous than they were in the past. This homogenization has resulted from regionwide losses, which have disproportionately affected the corals that previously dominated reef assemblages and were the primary constructors of reef framework.

During the early stages of the Holocene transgression, 12000 yr BP, actively growing coral reefs extended as far as $\sim 27^{\circ} \mathrm{N}$ in Florida (Shaler 1890, 
Banks et al. 2007). The acroporids built framework off eastern Florida until $6000 \mathrm{yr} \mathrm{BP}$, and have since been restricted to the shelf south of Miami $\left(25^{\circ}\right.$ $45^{\prime} \mathrm{N}$ ), following the mid-Holocene climatic optimum (Banks et al. 2007). Until 1977, coral assemblages north and south of Miami were differentiated based on the presence of the primary reef-building corals Acropora palmata, A. cervicornis, and Montastraea annularis species complex, all of which were more common south of Miami (Agassiz 1885, Vaughan 1919, Marszalek et al. 1977). The major cross-shelf zones south of Miami on the Florida reef tract were likewise defined by $A$. palmata, which dominated the reef crests; $A$. cervicornis, which dominated the patch reefs; and $M$. annularis complex, which dominated the deep forereefs and patch reefs (Goldberg 1973, Marszalek et al. 1977, Ginsburg et al. 2001).

Beginning in the late $1970 \mathrm{~s}$, the primary reefbuilding corals suffered extensive declines that were caused largely by coral disease, thermal stress, and mass mortality of the herbivorous echinoid Diadema antillarum (Gladfelter 1982, Rützler et al. 1983, Dustan \& Halas 1987, Jackson 1991, Aronson \& Precht 2001a, 2001b, Ginsburg et al. 2001, Patterson et al. 2002, Williams \& Miller 2005). Over the course of just 2 decades, white-band disease, followed by white-pox disease, virtually eliminated Acropora palmata and A. cervicornis from the Florida Keys (Gladfelter 1982, Porter \& Meier 1992, Aronson \& Precht 2001b, 2006; Patterson et al. 2002, Williams \& Miller 2005). Black-band disease reduced populations of Diploria strigosa and the Montastraea annularis complex (Rützler et al. 1983). $M$. annularis complex was further reduced in the early 1990s by yellow-band disease (Goreau et al. 1998). Death of the major reef-building corals led Jackson (1991) to point out that the reef zonation has 'changed, and there is little indication of rapid return to the original patterns.'

In 2005, the Florida Reef Resilience Program (FRRP) was established to examine the abundance of stony corals and the extent to which they were impacted by diseases and thermal disturbances in southern Florida. The FRRP used a probabilistic, 2-stage, stratified, randomized sampling strategy (Smith et al. 2011). The sampling domain was stratified a priori into subregions and reef-zones using geological and hydrographical features. The primary objective of the present study was to compare reef assemblages across depths, zones, and subregions to determine if homogenization had occurred and to what extent.

\section{MATERIALS AND METHODS}

\section{Sampling design}

The sampling domain of southern Florida was stratified into 14 reef zones and 9 geographic subregions ('sectors' in the terminology of Murdoch \& Aronson 1999) (Fig. 1). Within these stratified domains, the primary sampling sites $(200 \times 200 \mathrm{~m})$ were randomly selected. The number of sampling sites was weighted by the amount of available habitat. Sites were assessed at the second tier using 2 randomly selected transects, each of which was $10 \times 1 \mathrm{~m}$. Sites were randomized a priori, and given to the dive-boat captains as GPS points. Secondary localities were used whenever the primary localities fell over inappropriate habitats. Within each transect, each coral colony ( $>4 \mathrm{~cm}$ in diameter) was identified to species by divers and its diameter was measured to the nearest centimeter. Sampling sites were rerandomized for each sampling period, which took place in the summers. Additional sampling was conducted after major thermal-stress events. There were 9 sampling periods between August 2005 and September 2010 (see Fig. 2).

The reef zones and subregions were defined a priori by reef experts. We used 8 reef zones in the analysis (Table 1). (1) The Inshore Reefs ( $\mathrm{n}=210$ ) were inshore of Hawk Channel. This zone was pres-

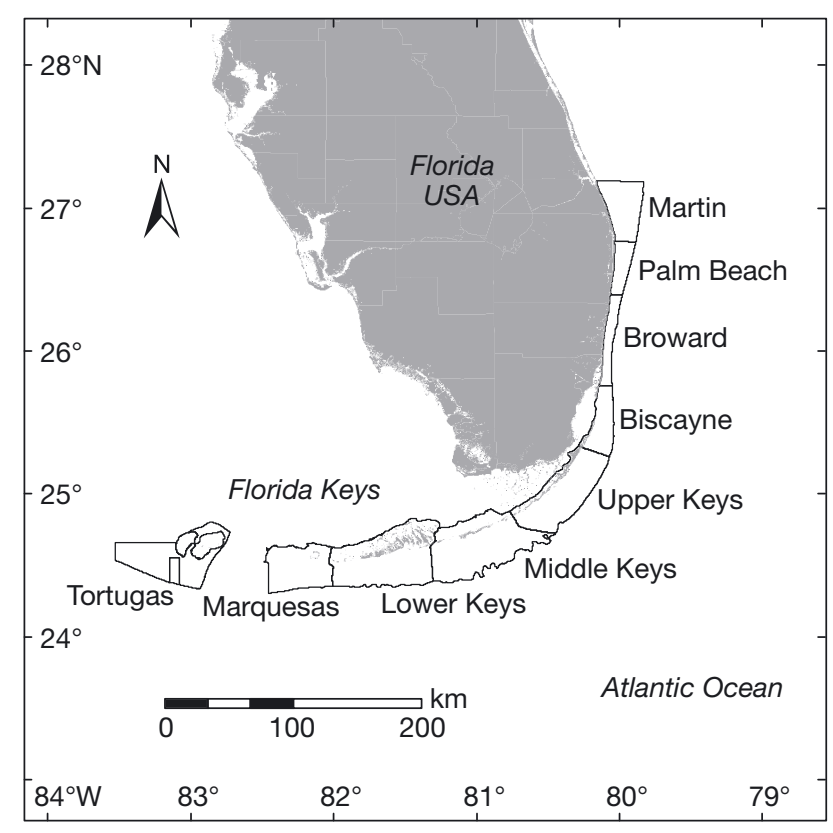

Fig. 1. Subregions within the study area, SE Florida and the Florida Keys (i.e. the Florida Reef Tract), USA 
ent in all subregions except Martin County and the Tortugas. (2) The Mid-Channel Reefs $(\mathrm{n}=205)$ were located within Hawk Channel. (3) The Offshore Patch Reefs $(\mathrm{n}=91)$ were patch reefs seaward of Hawk Channel. (4) Forereefs $(\mathrm{n}=478)$ were the reefs furthest from shore. They were found in all subregions except Martin, Palm Beach, and Broward Counties. (5) Undetermined Reef Zones ( $\mathrm{n}=$ 29) were located only in Martin County. (6) The Reef-Ridge Complex $(\mathrm{n}=34)$ was a system of patch reefs located exclusively in Palm Beach. (7) Inner Reefs $(\mathrm{n}=70)$ were similar to the Mid-Channel zone, but were located exclusively in Broward County, where Hawk Channel was poorly defined. (8) Outer Reefs $(n=55)$ were physiographically similar to Forereefs, but were located exclusively in Broward County (Table 1). Additional reef zones were identified a priori but were eliminated from the analysis because there was inadequate sampling: Deep Reefs $(n=6)$, Intra-Island Reefs $(n=1)$, Lagoon Reefs $(n=5)$, and Banks $(n=2)$.

The subregions, from north to south, were Martin County (number of sites: $n=29$ ), Palm Beach County $(\mathrm{n}=51)$, Broward County $(\mathrm{n}=253)$, Biscayne Bay $(\mathrm{n}=$ 192), Upper Keys $(\mathrm{n}=231)$, Middle Keys $(\mathrm{n}=122)$, Lower Keys ( $\mathrm{n}=251)$, Marquesas $(\mathrm{n}=6)$, Dry Tortugas $(\mathrm{n}=49)$, and Tortugas Bank $(\mathrm{n}=2)$ (Fig. 1). The Tortugas Bank was combined with the Dry Tortugas, yielding a Tortugas subregion $(n=51)$. On the mainland, subregions spanned roughly the coastal lengths of the respective counties. The Upper Keys subregion extended from Key Largo southwest through Tavernier. The Middle Keys subregion extended from Plantation Key west through Marathon, and the Lower Keys subregion extended from Ohio Key west through Key West.

Table 1. Cross-tabulation matrix indicating the zones that were present $(\bullet)$ in the respective subregions (1: Martin; 2: Palm Beach; 3: Broward; 4: Biscayne; 5: Upper Keys; 6: Middle Keys; 7: Lower Keys; 8: Marquesas; 9: Tortugas). Notably, many subregions contained unique zones not found in other subregions

\begin{tabular}{|c|c|c|c|c|c|c|c|c|c|}
\hline \multirow{2}{*}{ Reef zone } & \multicolumn{9}{|c|}{ - Subregion } \\
\hline & 1 & 2 & 3 & 4 & 5 & 6 & 7 & 8 & 9 \\
\hline Undetermined & - & & & & & & & & \\
\hline Reef Ridge Complex & & - & & & & & & & \\
\hline Inner Reef & & & - & & & & & & \\
\hline Outer Reef & & & $\bullet$ & & & & & & \\
\hline Inshore Reef & & - & - & - & - & - & - & - & \\
\hline Midchannel Reef & & & & & - & - & - & - & \\
\hline Offshore Patch Reef & & & & & $\bullet$ & - & - & - & \\
\hline Forereef & & & & - & - & - & $\bullet$ & $\bullet$ & - \\
\hline
\end{tabular}

Table 2. Global analysis of similarity (ANOSIM) statistics for each factor considered with 999 permutations and no permuted statistics greater than or equal to the Global R

\begin{tabular}{|lcc|}
\hline Factor & Global $\mathrm{R}$ & Global $\mathrm{p}$ \\
\hline Time & 0.03 & 0.001 \\
Depth & 0.115 & 0.001 \\
Subregion & 0.228 & 0.001 \\
Zone & 0.299 & 0.001 \\
\hline
\end{tabular}

\section{Data analysis}

Mean counts of coral colonies were calculated across transects within each $200 \times 200 \mathrm{~m}$ site. Organizational factors for each site included sampling period, depth, the 8 reef zones defined above, and the 9 subregions. To examine the extent of similarity in species assemblages across times, depths, zones, and subregions, we employed the analysis of similarities (ANOSIM; Primer 6 ${ }^{\circledR}$ ), using the Bray-Curtis similarity index, followed by pair-wise comparisons. The resemblance matrices of $\mathrm{R}$-values derived from the ANOSIMs were plotted using myImagePlot ${ }^{1}$ in $\mathrm{R}$ (R Development Core Team 2011). The individual colony diameters were summed for each transect. Within each site, the mean of the summed values from each transect was used as a proxy for percentage cover estimates. The means were interpolated over the Florida reef tract in ArcGIS 9.2, using an inverse distance weighting, calculated using the 10 nearest neighbor values within the sampling domain.

\section{RESULTS}

There was little variation in the ANOSIM R-scores across all 9 sampling periods (Table 2, Fig. 2), indicating that the samples were true replicates through time, regardless of season or year. The coral assemblages were also similar across depths (Table 2, Fig. 3), but they were less similar across zones (Table 2, Fig. 4). The mid-channel reefs, patch reefs, and forereefs south of Miami were dominated by Siderastrea siderea and Millepora alcicornis, each of which was over 6 times as abundant as the sum of Acropora cervicornis and the species of the Montastraea annularis complex (Table 3). The Undetermined zone, which was recorded only in the Martin subregion, was dominated by $S$. siderea, $S$. radians, and

\footnotetext{
1 Siedel C. Plotting a table of numbers as an image using R. Accessed 18 April 2012. www.phaget4.org/R/image_ matrix.html
} 
Diploria clivosa (Table 3). The zones in the Palm Beach and Broward subregions (Reef Ridge Complex, Inner Reef, and Outer Reef) were similar to each other in terms of coral species composition (Fig. 4). Those zones, found only from the Biscayne subregion south (Mid-Channel Reef, Offshore Patch Reef, and Forereef), were similar to each other (Fig. 4), indicating

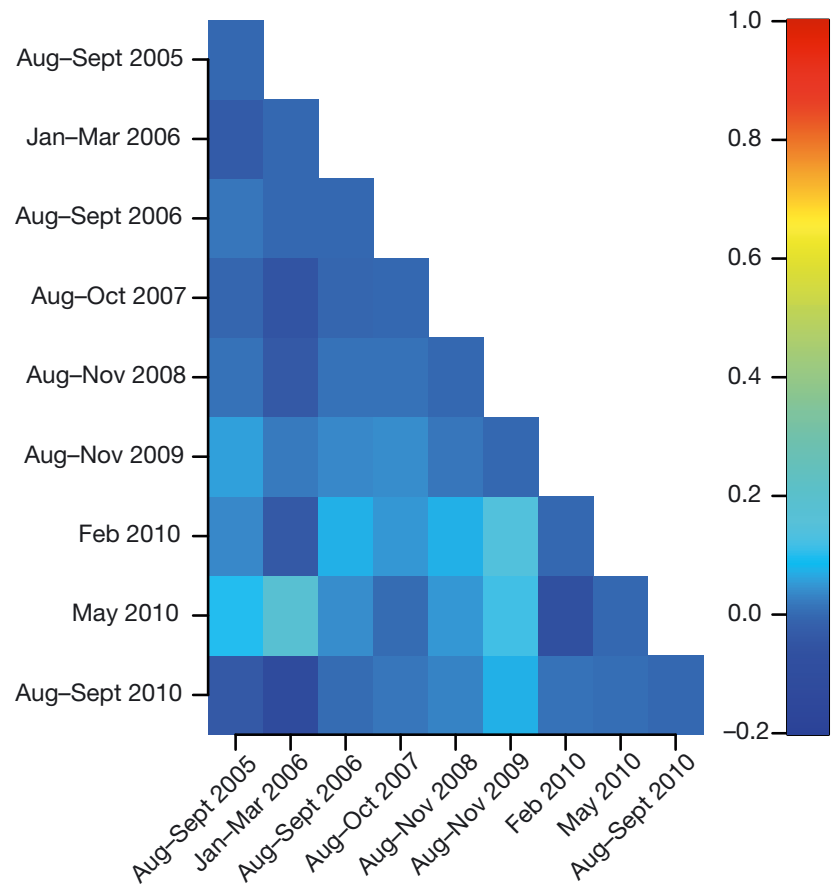

Fig. 2. ANOSIM R-score matrix comparing the sampling periods pairwise
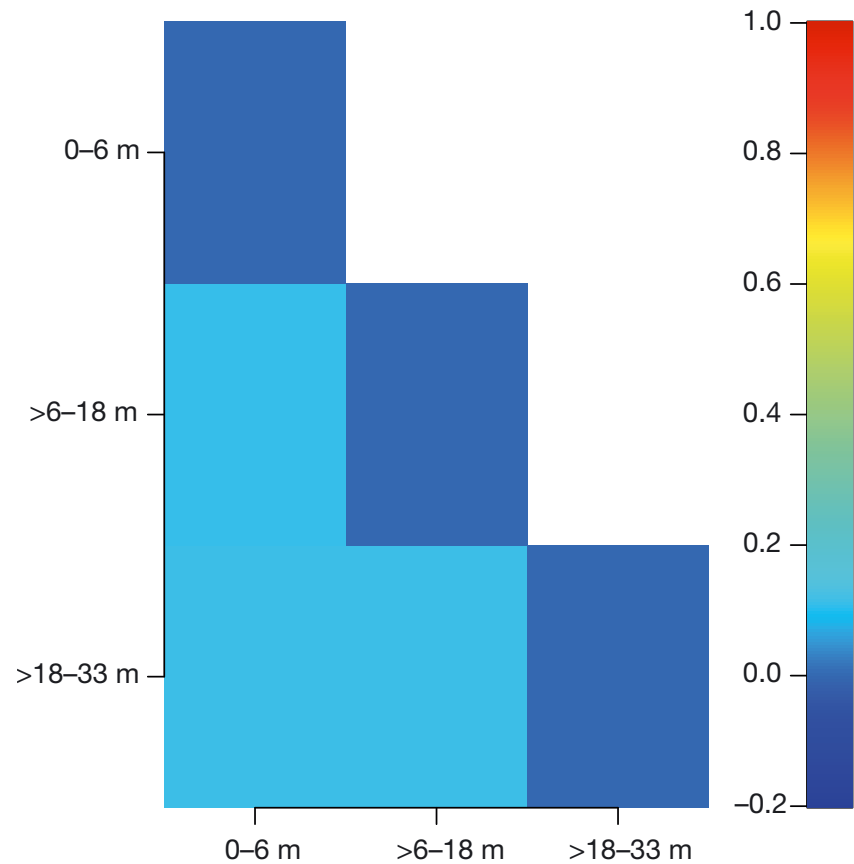

Fig. 3. ANOSIM R-score matrix comparing the depth classes pairwise that, south of Miami, the reefs were relatively homogeneous across the shelf (Fig. 4). The Inshore zones were similar across all subregions (Fig. 4).

There were 3 distinct sets of subregions (Table 2, Fig. 5). The Martin subregion was dominated by

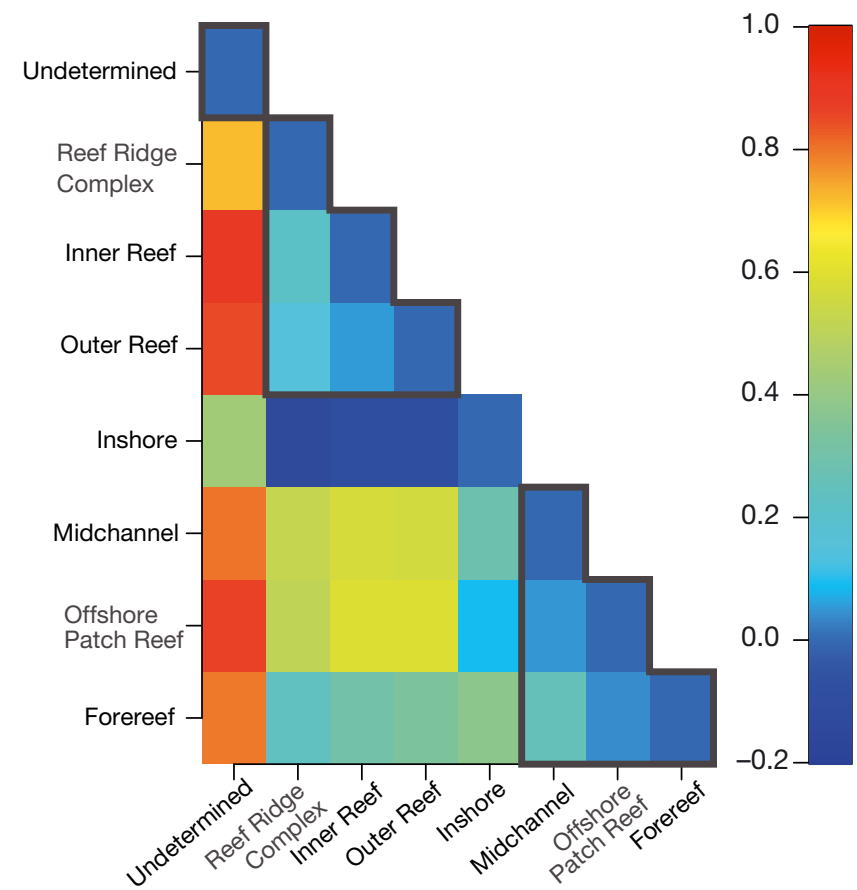

Fig. 4. ANOSIM R-score matrix comparing coral assemblages pairwise between reef zones. Similar zones are outlined in bold

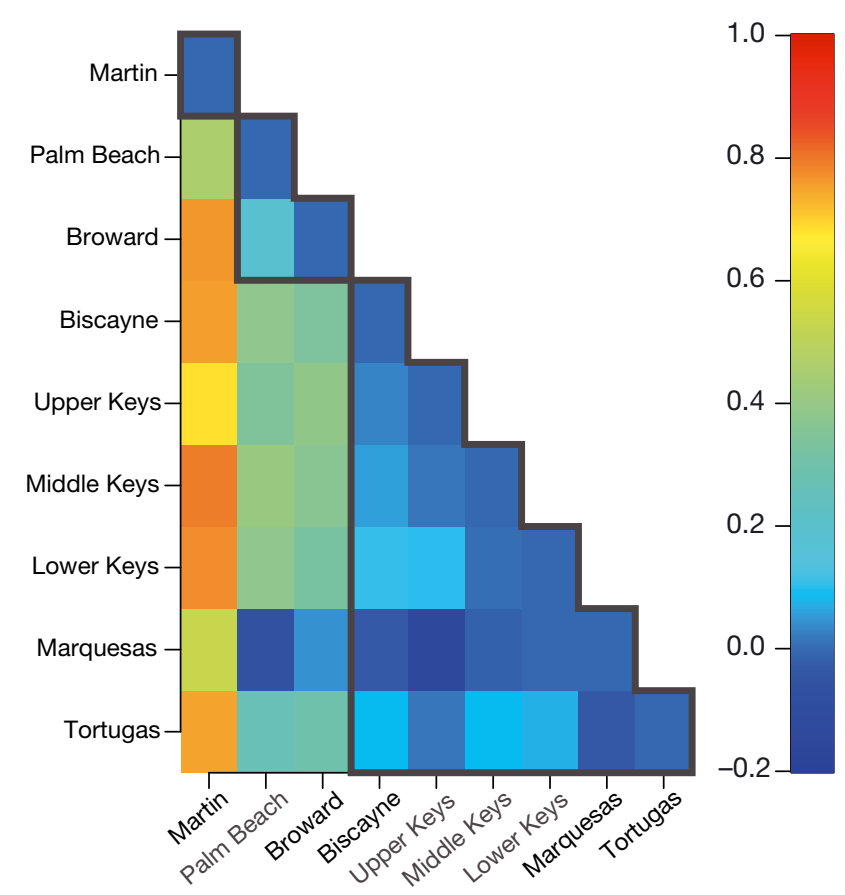

Fig. 5. ANOSIM R-score matrix comparing coral assemblages pairwise in the different subregions against each other. Subregions supporting similar coral assemblages are outlined in bold 
Table 3. Species-specific densities of coral colonies (per-site, per-transect) in the Florida reef tract by zone, sorted in descending order of mean abundance. -: species not present, or present at densities $<0.01$ colony per $10 \mathrm{~m}^{2}$

\begin{tabular}{|c|c|c|c|c|c|c|c|c|}
\hline Coral species & $\begin{array}{l}\text { Undetermined } \\
\text { Zone }\end{array}$ & $\begin{array}{l}\text { Ridge } \\
\text { Complex }\end{array}$ & Inner & Outer & Inshore & $\begin{array}{c}\text { Mid } \\
\text { Channel }\end{array}$ & $\begin{array}{l}\text { Offshore } \\
\text { Patch }\end{array}$ & $\begin{array}{l}\text { Fore- } \\
\text { reef }\end{array}$ \\
\hline Siderastrea siderea & 2.84 & 2.01 & 2.19 & 1.99 & 3.6 & 14.27 & 10.57 & 4.67 \\
\hline Millepora alcicornis & 0.4 & 3.94 & 2.71 & 2.11 & 2.35 & 6.58 & 10.2 & 10.82 \\
\hline Porites astreoides & 0.38 & 1.32 & 1.28 & 2.29 & 3.3 & 6.3 & 5.3 & 3.95 \\
\hline Stephanocoenia intersepta & 0.07 & 1.74 & 3.38 & 2.71 & 1.62 & 5.98 & 5.58 & 2.04 \\
\hline Montastraea cavernosa & 0.12 & 4.09 & 2.07 & 2.91 & 1.3 & 3.02 & 1.93 & 1.67 \\
\hline Porites porites & - & - & 0.34 & 0.24 & 0.7 & 3.14 & 3.01 & 1.35 \\
\hline Siderastrea radians & 2.59 & 0.99 & 0.26 & 0.15 & 1.02 & 1.3 & 0.72 & 0.7 \\
\hline Agaricia agaricites & - & 0.44 & 0.13 & 0.22 & 0.29 & 1.88 & 2.25 & 2.44 \\
\hline Dichocoenia stokesi & 0.07 & - & 0.51 & 0.41 & 1.09 & 2.35 & 1.85 & 0.93 \\
\hline Meandrina meandrites & - & 0.99 & 1.06 & 0.96 & 0.25 & 0.28 & 0.34 & 0.33 \\
\hline Montastraea faveolata & - & - & 0.17 & 0.2 & 0.38 & 1.75 & 0.8 & 0.61 \\
\hline Solenastrea bournoni & 0.1 & 0.25 & 0.31 & 0.18 & 0.84 & 0.78 & 0.55 & 0.25 \\
\hline Colpophyllia natans & - & 0.07 & 0.11 & 0.04 & 0.32 & 1.59 & 0.85 & 0.23 \\
\hline Diploria clivosa & 1.88 & - & 0.03 & - & 0.37 & 0.42 & 0.25 & 0.24 \\
\hline Diploria strigosa & 0.53 & 0.26 & 0.11 & 0.12 & 0.31 & 0.81 & 0.53 & 0.3 \\
\hline Porites furcata & - & - & - & - & 0.22 & 0.82 & 1.13 & 0.34 \\
\hline Porites divaricata & - & - & 0.07 & - & 0.24 & 0.34 & 1.26 & 0.2 \\
\hline Eusmilia fastigiata & - & 0.07 & 0.13 & 0.16 & 0.08 & 0.44 & 0.66 & 0.15 \\
\hline Montastraea annularis & - & 0.09 & - & 0.09 & 0.19 & 0.84 & 0.16 & 0.14 \\
\hline Montastraea franksi & - & 0.06 & - & 0.04 & 0.09 & 0.4 & 0.33 & 0.47 \\
\hline Diploria labyrinthiformis & - & - & - & - & 0.25 & 0.6 & 0.32 & 0.14 \\
\hline Madracis decactis & - & 0.34 & 0.44 & - & 0.08 & 0.05 & 0.13 & 0.24 \\
\hline Dendrogyra cylindrus & - & 1.09 & - & - & - & 0.01 & - & - \\
\hline Agaricia lamarcki & - & 0.06 & 0.07 & 0.11 & 0.02 & 0.17 & 0.41 & 0.21 \\
\hline Oculina diffusa & 1 & - & - & & 0.01 & 0.04 & - & - \\
\hline Madracis formosa & - & - & - & 0.95 & - & 0.03 & - & 0.04 \\
\hline Acropora cervicornis & - & - & - & - & 0.34 & 0.18 & 0.31 & 0.06 \\
\hline Millepora complanata & 0.17 & - & - & - & 0.01 & 0.07 & 0.08 & 0.27 \\
\hline Mussa angulosa & - & 0.06 & 0.03 & - & 0.01 & 0.21 & 0.07 & 0.01 \\
\hline Favia fragum & - & - & 0.03 & - & 0.07 & 0.1 & 0.08 & 0.07 \\
\hline Solenastrea hyades & - & - & - & - & 0.04 & 0.07 & 0.13 & 0.04 \\
\hline Isophyllia sinuosa & 0.07 & - & - & - & 0.03 & 0.13 & - & 0.01 \\
\hline Agaricia fragilis & - & - & 0.09 & 0.12 & 0.03 & - & - & - \\
\hline Porites branneri & - & - & - & - & 0.01 & 0.08 & 0.02 & 0.11 \\
\hline Manicina areolata & - & - & - & - & 0.04 & 0.05 & 0.08 & 0.04 \\
\hline Madracis mirabilis & - & 0.09 & - & - & 0.01 & 0.03 & 0.03 & 0.03 \\
\hline Leptoseris cucullata & - & - & - & - & - & 0.02 & 0.14 & 0.02 \\
\hline Cladocora arbuscula & - & - & - & - & 0.01 & 0.06 & 0.02 & - \\
\hline Mycetophyllia aliciae & - & - & - & 0.05 & - & - & - & 0.01 \\
\hline Scolymia cubensis & - & - & 0.06 & - & - & - & - & - \\
\hline Agaricia humilis & - & - & - & - & _- & 0.05 & _- & _- \\
\hline Isophyllastrea rigida & - & - & - & - & - & 0.02 & - & 0.02 \\
\hline Acropora palmata & - & - & - & - & - & - & - & 0.03 \\
\hline Mycetophyllia ferox & - & - & - & - & - & 0.02 & - & 0.01 \\
\hline
\end{tabular}

Siderastrea siderea, S. radians, and Diploria clivosa (Table 4). Palm Beach and Broward supported coral assemblages that were similar to each other but different from elsewhere (Table 4, Fig. 5), dominated by Porites astreoides, Millepora alcicornis, Stephanocoenia intersepta, Montastraea cavernosa, and S. siderea (Table 3). The third set of subregions incorporated Biscayne, Upper Keys, Middle Keys, Lower Keys, Marquesas, and Tortugas (Fig. 5). This third set was dominated by $M$. alcicornis, $S$. siderea, $P$. astreoides, Stephanocoenia intersepta, Agaricia agaricites, Montastraea cavernosa, P. porites, and Dichocoenia stokesi (Table 4). Therefore, of the 9 putative subregions, 6 were found to be redundant on the basis of coral composition. The reefs still varied spatially, however, with some localities supporting more large colonies than other localities (Fig. 6).

\section{DISCUSSION}

Prior to the 1970s, the reefs of southern Florida supported 'luxuriant' growth of Acropora cervicornis (Agassiz 1885) on patch reefs, dense stands of A. pal- 
Table 4. Species-specific densities of coral colonies (per-site, per-transect) in the Florida reef tract defined as amalgamations of subregions, sorted in descending order of mean abundance. -: species not present or present at densities $<0.01$ colony per $10 \mathrm{~m}^{2}$

\begin{tabular}{|c|c|c|c|}
\hline Coral species & Martin & $\begin{array}{c}\text { Palm } \\
\text { Beach, } \\
\text { Broward }\end{array}$ & $\begin{array}{l}\text { South of } \\
\text { Miami }\end{array}$ \\
\hline Siderastrea siderea & 2.84 & 1.87 & 7.84 \\
\hline Millepora alcicornis & 0.4 & 2.39 & 9.19 \\
\hline Porites astreoides & 0.38 & 2.4 & 4.6 \\
\hline Stephanocoenia intersepta & 0.07 & 2.09 & 3.39 \\
\hline Montastraea cavernosa & 0.12 & 2.09 & 2.04 \\
\hline Siderastrea radians & 2.59 & 0.41 & 0.96 \\
\hline Porites porites & - & 0.45 & 1.9 \\
\hline Diploria clivosa & 1.88 & 0.18 & 0.29 \\
\hline Agaricia agaricites & - & 0.2 & 2.13 \\
\hline Dichocoenia stokesi & 0.07 & 0.71 & 1.41 \\
\hline Diploria strigosa & 0.53 & 0.15 & 0.49 \\
\hline Solenastrea bournoni & 0.1 & 0.53 & 0.45 \\
\hline Montastraea faveolata & - & 0.11 & 0.94 \\
\hline Oculina diffusa & 1 & 0.01 & 0.01 \\
\hline Meandrina meandrites & - & 0.68 & 0.32 \\
\hline Colpophyllia natans & - & 0.11 & 0.66 \\
\hline Madracis decactis & - & 0.4 & 0.17 \\
\hline Porites furcata & - & - & 0.57 \\
\hline Montastraea franksi & - & 0.02 & 0.44 \\
\hline Porites divaricata & - & 0.04 & 0.38 \\
\hline Montastraea annularis & - & 0.04 & 0.34 \\
\hline Eusmilia fastigiata & - & 0.09 & 0.28 \\
\hline Millepora complanata & 0.17 & 0.01 & 0.19 \\
\hline Diploria labyrinthiformis & - & 0.02 & 0.32 \\
\hline Acropora cervicornis & - & 0.23 & 0.11 \\
\hline Agaricia lamarcki & - & 0.07 & 0.21 \\
\hline Isophyllia sinuosa & 0.07 & - & 0.05 \\
\hline Favia fragum & - & 0.02 & 0.08 \\
\hline Porites branneri & - & - & 0.09 \\
\hline Mussa angulosa & - & 0.01 & 0.07 \\
\hline Manicina areolata & - & - & 0.06 \\
\hline Solenastrea hyades & - & - & 0.06 \\
\hline Agaricia fragilis & - & 0.06 & - \\
\hline Leptoseris cucullata & - & 0.01 & 0.03 \\
\hline Madracis mirabilis & - & 0.01 & 0.03 \\
\hline Madracis formosa & - & - & 0.03 \\
\hline Acropora palmata & - & - & 0.02 \\
\hline Cladocora arbuscula & - & - & 0.02 \\
\hline Isophyllastrea rigida & - & - & 0.02 \\
\hline Agaricia humilis & - & - & 0.01 \\
\hline Mycetophyllia ferox & - & - & 0.01 \\
\hline Mycetophyllia aliciae & - & 0.01 & - \\
\hline Mycetophyllia lamarckiana & - & 0.01 & - \\
\hline Scolymia cubensis & - & 0.01 & - \\
\hline
\end{tabular}

mata on the forereef, and clusters of Montastraea annularis complex throughout (Agassiz 1885, Vaughan 1919, Goldberg 1973, Marszalek et al. 1977). These once-abundant coral species, which delineated the reefs south of Miami in the past, have been particularly vulnerable to infectious diseases and thermal stress, and have been replaced by more

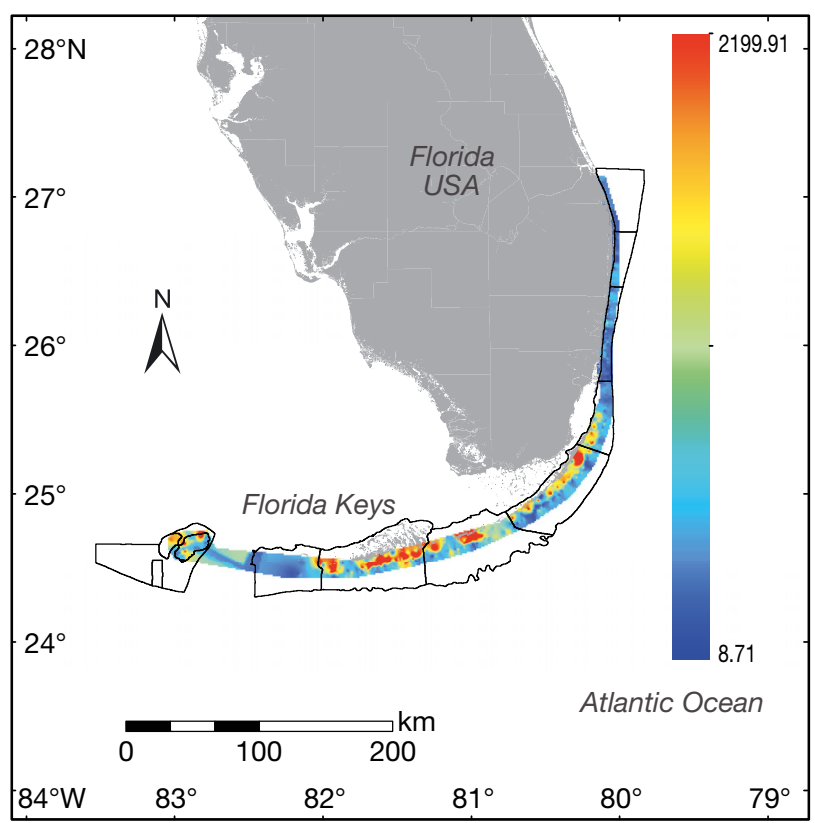

Fig. 6. Spatial distribution of the means of the summed diameters of coral colonies per site in the study region, interpolated using an inverse distance weighting with the 10 nearest neighbors for each site. Red: abundant, large colonies; blue: few, small coral colonies

tolerant species. Siderastrea siderea is now the most abundant coral species on the Florida reef tract: it is twice as abundant as any other scleractinian coral species (Table 4). South of Miami, M. cavernosa was previously less common than the $M$. annularis complex (Goldberg 1973), but $M$. cavernosa is more abundant on contemporary reefs than its congeners (Table 3). The reefs south of Miami are now considerably less distinct than they were in the past, both from each other and from the reefs north of Miami (Agassiz 1885, Goldberg 1973, Marszalek et al. 1977). A. cervicornis and A. palmata, formerly dominant on reefs south of Miami (Agassiz 1885, Marszalek et al. 1977), are virtually absent from contemporary reefs and can no longer be considered meaningful contributors to cross-shelf zonation (Table 4).

The dramatic decline of corals on the Florida reef tract has not been uniform. The species that have declined the most are the ones that were most significant in delineating zones and subregions. These corals were also the most stenotopic species - able to tolerate only a narrow range of environmental conditions. Their loss leaves eurytopic, generalist species as the dominants today (Tables 2 \& 3). The transition in dominance from stenotopic to eurytopic coral species mirrors similar transitions elsewhere in the 
Caribbean, both in recent decades and in the geologic past (Edinger \& Risk 1994, Budd \& Johnson 1999, Aronson \& Precht 2001a, Green et al. 2008, Klaus et al. 2011, van Woesik et al. 2012).

The generalists, including Siderastrea spp., Porites spp., Montastraea Cavernosa, and Agaricia spp., have withstood a number of recent perturbations, including thermal stress and disease. The present assemblages, therefore, are likely to be more stable than those of the past (Côté \& Darling 2010), but coral assemblages without framework-building species are clearly less desirable in terms of the ecosystem services they provide. The loss of framework-building species has biologically homogenized and impoverished the reef system, has greatly reduced its capacity to construct reef framework, and has made it undesirably stable and resistant to change. On the other hand, the reefs still vary spatially, with some localities supporting more colonies than others (Fig. 6). The localities with the best coral coverage are seaward of the largest keys, and are not directly in the channels connected to Florida Bay. These localities were also the ones described by Marszalek et al. (1977) as supporting the 'most luxuriant' coral reefs. The greatest variances in coral-colony density and colony diameter, on contemporary reefs occurred at the scale of $\sim 10$ to $20 \mathrm{~km}$ (Fig. 6), which is approximately the same scale at which Murdoch \& Aronson (1999) detected the greatest variance in coral cover along the Florida reef tract.

Given the currently homogenized state of the coral assemblages on reefs in the Florida reef tract, is it wiser to put our limited resources into restoring the endangered acroporids, or would it be better to focus on the more feasible enterprise of supporting the eurytopic species? Restoring the acroporids is a laudable goal, but active restoration is both difficult and expensive (Herlan \& Lirman 2008). Reef managers should embrace the reality that Florida's reefs have changed fundamentally. We advocate a bet-hedging strategy as the optimal response to the homogenization of coral assemblages along the Florida reef tract. Maximizing the coverage of eurytopic coral species, many of which are self-fertilizing hermaphrodites that release brooded larvae, will not substantially increase reef-framework construction. The effort could, however, maintain some functional attributes of coral reefs, such as preventing the degradation of existing frameworks. Maintaining the integrity of the frameworks would provide substratum for the more limited artificial seeding of the reefs with acroporids. Ideally, the acroporids could then increase on their own through fragmentation.
Acknowledgements. We thank J. Byrne, C. Berg, and P. Kramer from The Nature Conservancy for providing research funding since 2005, NOAA's Coral Reef Conservation Program for providing salary support, all the volunteers who spent endless hours on the reefs of the Florida reef tract collecting the data, and S. van Woesik for editorial comments on the manuscript. This paper is Contribution No. 72 from the Institute for Research on Global Climate Change at the Florida Institute of Technology.

\section{LITERATURE CITED}

Agassiz A (1885) Explorations of the surface fauna of the Gulf Stream, under the auspices of the United States Coast Survey. II. The Tortugas and Florida reefs. Mem Am Acad Arts Sci 11(2:1):106-133

Aronson RB, Precht WF (2001a) Evolutionary paleoecology of Caribbean coral reefs. In: Allmon WD, Bottjer DJ (eds) Evolutionary paleoecology: the ecological context of macroevolutionary change. Columbia University Press, New York, NY, p 171-233

Aronson RB, Precht WF (2001b) White-band disease and the changing face of Caribbean coral reefs. Hydrobiologia 460:25-38

Aronson RB, Precht WF (2006) Conservation, precaution, and Caribbean reefs. Coral Reefs 25:441-450

> Banks KW, Riegl BM, Shinn EA, Piller WE, Dodge RE (2007) Geomorphology of the southeast Florida continental reef tract (Miami-Dade, Broward, and Palm Beach Counties, USA). Coral Reefs 26:617-633

Budd AF, Johnson KG (1999) Origination preceding extinction during late Cenozoic turnover of Caribbean reefs. Paleobiology 25:188-200

Côté IM, Darling ES (2010) Rethinking ecosystem resilience in the face of climate change. PLoS Biol 8:e1000438

> Doak DF, Bigger D, Harding EK, Marvier MA, O'Malley RE, Thomson D (1998) The statistical inevitability of stabilitydiversity relationships in community ecology. Am Nat 151:264-276

$>$ Dustan P, Halas JC (1987) Changes in the reef-coral community of Carysfort Reef, Key Largo, Florida: 1974 to 1982. Coral Reefs 6:91-106

Edinger EN, Risk MJ (1994) Oligocene-Miocene extinction and geographic restriction of Caribbean corals: roles of turbidity, temperature, and nutrients. Paleobiology 21: 200-219

> Elmqvist T, Folke C, Nyström M, Peterson G, Bengtsson J, Walker B, Norberg J (2003) Response diversity, ecosystem change, and resilience. Front Ecol Environ 1: 488-494

Ginsburg RN, Gischler E, Kiene WE (2001) Partial mortality of massive reef-building corals: an index of patch reef condition, Florida reef tract. Bull Mar Sci 69:1149-1173

Gladfelter WB (1982) White-band disease in Acropora palmata: implications for the structure and growth of shallow reefs. Bull Mar Sci 32:639-643

Goldberg WM (1973) The ecology of the coral-octocoral communities off the southeast Florida coast: geomorphology, species composition, and zonation. Bull Mar Sci 23:465-488

Goreau TJ, Cervino J, Goreau M, Hayes R, and others (1998) Rapid spread of diseases in Caribbean coral reefs. Rev Biol Trop 46 (Suppl 5):157-171

> Green DH, Edmunds PJ, Carpenter RC (2008) Increasing 
relative abundance of Porites astreoides on Caribbean reefs mediated by an overall decline in coral cover. Mar Ecol Prog Ser 359:1-10

Herlan J, Lirman D (2008) Development of a coral nursery program for the threatened coral Acropora cervicornis in Florida. Proc 11th Int Coral Reef Symp 2:1249-1252

> Jackson JBC (1991) Adaptation and diversity of reef corals. BioScience 41:475-482

Jousson O, Pawlowski J, Zaninetti L, Meinesz A, Boudouresque $C$ (1998) Molecular evidence for the aquarium origin of the green alga Caulerpa taxifolia introduced the Mediterranean Sea. Mar Ecol Prog Ser 172:275-280

Klaus JS, Lutz BP, McNeill DF, Budd AF, Johnson KG, Ishman SE (2011) Rise and fall of Pliocene free-living corals in the Caribbean. Geology 39:375-378

Marszalek DS, Babashoff G Jr, Noel MR, Worley DR (1977) Reef distribution in south Florida. Proc 3rd Int Coral Reef Symp 2:223-230

Murdoch TJT, Aronson RB (1999) Scale-dependent spatial variability of coral assemblages along the Florida Reef Tract. Coral Reefs 18:341-351

Olden JD, Poff NL (2003) Toward a mechanistic understanding and prediction of biotic homogenization. Am Nat 162:442-460

Patterson KL, Porter JW, Ritchie KB, Polson SW and others (2002) The etiology of white pox, a lethal disease of the Caribbean elkhorn coral, Acropora palmata. Proc Natl Acad Sci USA 99:8725-8730

Porter JW, Meier OW (1992) Quantification of loss and change in Floridian reef coral populations. Am Zool 32: 625-640

Editorial responsibility: Peter Edmunds, Northridge, California, USA
R Development Core Team (2011) R: A language and environment for statistical computing. R Foundation for Statistical Computing, Vienna. www.R-project.org

Rooney TP, Wiegmann SM, Rogers DA, Waller DM (2004) Biotic impoverishment and homogenization in unfragmented forest understory communities. Conserv Biol 18: $787-798$

Rützler K, Santavy DL, Antonius A (1983) The black band disease of Atlantic reef corals. PSZN I: Mar Ecol 4: 329-358

Shaler NS (1890) The topography of Florida. Bull Mus Comp Zool 16:139-158

Smith SG, Swanson DW, Chiappone M, Miller SL, Ault JS (2011) Probability sampling of stony coral populations in the Florida Keys. Environ Monit Assess 183:121-138

Thrush SF, Halliday J, Hewitt JE, Lohrer AM (2008) The effects of habitat loss, fragmentation, and community homogenization on resilience in estuaries. Ecol Appl 18: 12-21

Tilman D, Lehman CL, Bristow CE (1998) Diversity stability relationships: statistical inevitability or ecological consequence? Am Nat 151:277-282

van Woesik R, Franklin EC, O'Leary J, McClanahan TR, Klaus JS, Budd AF (2012) Hosts of the Plio-Pleistocene past reflect modern-day coral vulnerability. Proc R Soc Lond B Biol Sci 279:2448-2456

Vaughan TW (1919) Corals and the formation of coral reefs. Smithsonian Ann Rep 1919:189-275

Williams DE, Miller MW (2005) Coral disease outbreak: pattern, prevalence and transmission in Acropora cervicornis. Mar Ecol Prog Ser 301:119-128

Submitted: April 30, 2012; Accepted: July 20, 2012

Proofs received from author(s): October 14, 2012 